Forthcoming at Sociological Forum

\title{
"I Don't Want Everybody to Vote": Christian Nationalism and Restricting Voter Access in the United States ${ }^{1}$
}

\author{
Samuel L. Perry \\ Department of Sociology \\ University of Oklahoma \\ Andrew L. Whitehead \\ Department of Sociology \\ Indiana University-Purdue University Indianapolis \\ Joshua B. Grubbs \\ Department of Psychology \\ Bowling Green State University
}

\begin{abstract}
Though the persistence of voter suppression and disenfranchisement in the US is welldocumented, we still know little about their contemporary ideological underpinnings beyond partisanship and racial resentment. Highlighting the Christian Right's influence in driving antidemocratic sentiment in the post-Civil Rights era, we propose contemporary ideological support for restricting the vote generally, and specifically, to those who prove "worthy," is undergirded by a pervasive ideology that cloaks authoritarian ethno-traditionalism with the ultimacy and polysemic utility of religious language-Christian nationalism. Nationally representative data collected weeks before the November 2020 elections reveal Christian nationalism is a leading predictor that Americans deny that voter suppression is a problem, believe that the US makes it "too easy to vote," believe that voter fraud is rampant, and support measures to disenfranchise individuals who could not pass a basic civics test or who committed certain crimes. Interactions show Christian nationalism's influence is particularly strong among men across most outcomes and, regarding voter suppression, whites compared to Blacks. We argue Christian nationalism seeks to institutionalize founding ideals in which civic participation is rooted in hierarchies, being restricted to a "worthy" few. Appeals to America's religious heritage thus facilitate stratifying America's citizenry and justifying restricting participation to preserve dominance.
\end{abstract}

Keywords: voting rights, voter fraud, voter suppression, 2020 election, disenfranchisement, Christian nationalism

\footnotetext{
${ }^{1}$ Direct all correspondence to : Samuel L. Perry, mail: Department of Sociology, University of Oklahoma, 780 Van Vleet Oval, Kaufman Hall, Norman, OK 73072; email: samperry@ou.edu.
} 
Though the Declaration of Independence asserts that governments derive their just powers "from the consent of the governed," those who are able to influence laws and institutions have perpetually sought to preserve their power by restricting which of "the governed" can participate in the governing process (see historical accounts in Anderson 2018; Berman 2015; Daniels 2020; Hartmann 2020; Keyssar 2000; Roth 2016; Waldman 2016; Wang 2012). At the nation's founding, less than $10 \%$ of those ruled by governing authorities (only $15 \%$ of the free adult population) could vote. With few exceptions, this was almost exclusively white propertied Protestant men, thus excluding poorer whites; most Catholics, Jews, and Quakers; Native Americans; non-English speakers; Blacks (slave or free); and all women (Ratcliffe 2013). Progressively these groups were formally enfranchised in fits and starts, starting with poorer whites including white religious minorities, then free or formerly enslaved Black men; later some Native American men; then women; then all Native Americans, and so on. Yet even as minority citizens were legally enfranchised, entire regions of the country sought to disenfranchise and suppress their votes through a variety of means (Berman 2015; Daniels 2020; Hartmann 2020; Manza and Uggen 2006), often baldly in the service of maintaining hegemonic domination, but also ostensibly under a sincere (anti-egalitarian and undemocratic) belief that only certain citizens "deserved" to have a say in governance (Anderson 2018; Keyssar 2000; Roth 2016).

Though a considerable body of research sought to understand the ongoing strategies of disenfranchisement and voter suppression in the United States (Anderson 2018; Berman 2015; Daniels 2020; Hartmann 2020; Roth 2016; Wang 2012), we still know relatively little about the ideological underpinnings of these efforts. Specifically, what are the dominant ideological frames that underlie negative views toward voting access and participation, and ultimately, rationalize efforts to restrict the vote to a "worthy" few? Though existing research has long 
connected support for modern modes of voter suppression and disenfranchisement (e.g., strict voter ID laws, felon disenfranchisement) to white supremacy, reactionary politics, and increasingly, extreme partisanship (Atkeson et al. 2014; Banks and Hicks 2016; Bentele and O'Brien 2013; Stewart et al. 2016; Udani and Kimball 2018; Wilson and Brewer 2013), we propose that political theology unites these elements while also supplying critical tools for rationalizing and preserving institutional norms surrounding both practices in the post-Civil Rights era. Recounting the centrality of the Christian Right to historical and contemporary efforts at voter suppression and disenfranchisement, we theorize that contemporary ideological support for restricting the vote generally, and specifically, to those who prove "worthy," is supplied by a pervasive ideology that cloaks authoritarian ethno-traditionalism with the ultimacy and polysemic utility of religious language-what scholars have called "Christian nationalism" (Bean 2014; Gorski and Perry 2022; Marti 2020; Whitehead and Perry 2020).

Testing this theory with recent, nationally-representative data, we document that Christian nationalist ideology is among the leading predictors (and most often the leading predictor) that Americans deny that voter suppression in Presidential elections is an ongoing problem, believe the United States makes it "too easy to vote," believe that voter fraud is rampant, and would support measures to restrict the vote to persons who could pass a basic civics test and disenfranchise certain criminal offenders for life. We also demonstrate that these associations are often slightly more pronounced among men and, regarding voter suppression, whites compared to Blacks. Importantly, all trends are robust even after accounting for Americans' political characteristics, traditional measures of religious commitment and conservatism, and even perceptions of ethnoracial discrimination, indicating that Christian nationalism is not merely a proxy for partisan tribalism, theological exclusivity, or racial threat. 
Rather, it operates as a unique ideological frame that undergirds Americans' desires to restrict and monopolize political participation so as to preserve (sanctified) privilege if not institutional power for white cultural conservatives.

Our findings make several critical contributions to understanding the current American political landscape. First and foremost, because voting is the bedrock foundation of the democratic process, and efforts at restricting voter enfranchisement and access continue to play a formidable role in biasing outcomes for the Republican Party (Hajnal et al. 2017, 2018; Kuk et al. 2020; Uggen and Manza 2002), our findings cut to the very heart of contemporary threats to free and fair elections by highlighting how ostensibly religious views about America's Christian character mask authoritarian and hierarchical ideals of merit, inclusion, and access. ${ }^{2}$ Second, and related to this last point, our findings underline the pernicious threat that religious nationalist movements pose to democracy itself, not just in shoring up support for certain political candidates or their positions on polarizing issues (e.g., Gorski and Perry 2022; Stroope et al. 2020; Whitehead, Perry, and Baker 2018), but potentially in supporting efforts to neutralize perceived threats from minority groups by subverting participation in elections. Third, despite the documented influence of political partisanship and ideology as well as perceptions of racial threat in shaping Americans' views on voter suppression and disenfranchisement, our findings demonstrate the uniqueness of Christian nationalism as a factor in maintaining and reproducing

\footnotetext{
2 Though the efficacy of tactics like strict voter ID laws to advantage Republicans has been scrutinized and debated (e.g., Grimmer et al. 2018; Mycoff et al. 2009; Rocha and Matsubayashi 2014), the most recent research suggest restrictive voting laws are not only intended to disadvantage minority voters, but in fact do so (Hajnal et al. 2018; Kuk et al. 2020; Uggen and Manza 2002), and the extent to which these effects are not perceived may in fact be due the efficacy of counter-mobilization on the part of Democrats (Valentino and Neuner 2017).
} 
power hierarchies at the ideological, and ultimately, institutional level. Thus, we underscore the essential inclusion of political theology in sociological analyses of systemic inequality.

\section{PUBLIC OPINION TOWARD VOTING, VOTER SUPPRESSION, AND VOTER}

\section{DISENFRANCHISEMENT}

Likely because few Americans would want to affirm being overtly anti-democratic in the post-Civil Rights era, little research explored explicit indicators of support for voter suppression. Rather, most of the literature on Americans' views regarding voter access examines support for more subtle and reasoned methods of limiting voter access such as voter ID laws and, to a much lesser extent, felon disenfranchisement. ${ }^{3}$

\section{Restricting Voter Access}

\footnotetext{
${ }^{3}$ Though voter ID laws have been in place in various states since the 1950 s, Republicandominated states began adopting them in earnest during the early $2000 \mathrm{~s}$, and at an even more accelerated rate since 2010, ostensibly as a means of deterring "voter fraud," most often without any evidence that systematic voter fraud exists (Minnite 2010; see also Anderson 2018; Berman 2015; Roth 2016). In fact, studies show that the proposal and adoption of voter ID laws are closely connected to racial resentment and partisanship. Analyzing the voting behavior of state legislators at the district level, McKee (2015) documented that as the size of the Black population in a district increased, so did the likelihood that a Republican lawmaker would vote for a restrictive voter ID bill. Similarly, Hicks et al. (2015) analyzed voter ID legislation in states from 2001-2012 and found the prevalence of Republican lawmakers in a state strongly predicted the adoption of voter ID laws, particularly if they were in competitive states, indicating that "the furtherance of restrictive voter ID laws is means of maintaining Republican support while curtailing Democratic gains." Focusing on which states adopted early voting policies over several decades, Biggers and Hanmer (2015) showed states with Republican governors were less likely to implement early voting. And expanding the analysis beyond voter ID or early voting policies to include multiple forms of restrictive voter access policies from 2006-2011 (e.g., requiring photo ID and proof of citizenship, registration restrictions, absentee ballot voting restrictions, reductions of early voting), Bentele and O'Brien (2013) demonstrate that such efforts are highly partisan with the goal of demobilizing minority voters and specifically Black Americans. This strategy of disproportionately burdening minorities and discouraging turnout is not just fundamentally anti-democratic in its intentions (Anderson 2018), but as political scientists (e.g., Hajnal et al. 2017; Kuk et al. 2020) have demonstrated, it is effective.
} 
Research examining public opinion toward restrictive voter access policies has focused almost exclusively on partisanship, political messaging, and racial threat or prejudice as the central drivers. Early research by Ansolabehere and Persily in the mid-2000s (2008; see also Conover and Miller 2017) found Republican identification and conservative political ideology were key predictors that Americans thought voter fraud, theft, and impersonation were common, though this belief was unrelated to whether Americans had voter ID laws in their state. Looking at attitudes toward voter ID laws specifically, Wilson and Brewer (2013) found that support was strongly connected to Republican identification, exposure to Fox News, belief that voter fraud is prevalent, and resentment toward any special considerations given to African Americans for past injustices. Subsequent experimental studies (Banks and Hicks 2016; Wilson et al. 2014) demonstrate how racialized public opinion toward voter ID laws can be, finding whites who are primed with fear or even merely shown pictures of Black voters or poll workers are more likely to support voter ID laws. Atkeson et al. (2014; see also Kane 2017) also found that Republican party identification strongly predicted adults' support for voter ID laws, and that they consider preventing fraud more important than ensuring access to the polls. Interestingly, despite the ostensible goal of ensuring greater confidence in election outcomes, Stewart et al. (2016) show that citizens who live in states with voter ID laws do not have greater confidence in elections or perceive lower rates of voter impersonation fraud, but rather partisan identification largely explained both support for ID laws and the perception that voter fraud is rampant.

\section{Disenfranchisement}

Another technique for potentially manipulating electoral outcomes in addition to voter suppression is outright disenfranchisement. In the post-Civil Rights era such efforts have largely focused on prison populations and at different times those with felony convictions. Two studies 
from the early 2000s found that while most Americans favored disenfranchising prison inmates, the majority also favored re-enfranchising former felons after serving their sentence, even while on parole (Manza et al. 2004; Pinaire and Heumann 2003). Notably, however, Manza et al. (2004) also found support for re-enfranchising declined depending on the stigma attached to the crime, suggesting fear and punitiveness compete with any underlying belief in the voting rights of all citizens. Recent polling results from Pew Research Center (Bialik 2018) show the vast majority of Americans (69\%) still support allowing former felons to vote after serving their sentences. Political partisanship affects these views, however, with only 55\% of Republicans favoring re-enfranchising felons compared to $82 \%$ of Democrats.

Indeed, Pew finds consistent evidence that while the majority of Americans support policies that would allow for greater voting ease and access, majorities of Republicans often favor restrictive policies. For example, less than half of Republicans favor allowing people to register on Election Day at the polls (49\%) or policies that would automatically register all eligible citizens (49\%); over half (53\%) support purges of voter registration lists of people who have not recently voted; and unsurprisingly, about $91 \%$ support requiring all voters show government issued photo ID to vote.

Importantly, none of the research on public opinion toward voter access or disenfranchisement policies consider the role of religion in any form. Yet partisanship, ideology, and racial identity and attitudes have long closely aligned with religious characteristics. And as studies consistently show, this is even more true in recent decades (McDaniel and Ellison 2008; O'Brien and Abdelhadi 2020). And recent research has called for sociologists to recognize their connection within political analyses (e.g., Gorski and Perry 2022; Perry and Whitehead 2021; Wilde and Glassman 2016). Building on a burgeoning body of literature identifying Christian 
nationalism as a core political theology driving conservative politics in recent decades, we theorize that it also serves to motivate and tacitly justify the anti-democratic impulses leading some Americans to favor limiting political participation in general, dismiss charges of voter suppression, espouse conspiratorial views about voter fraud, and favor policies restricting the vote to a circumscribed group deemed "worthy."

\section{CHRISTIAN NATIONALISM AS A CRITICAL IDEOLOGICAL FOUNDATION FOR RESTRICTING VOTING ACCESS}

Following recent research (e.g., Bean 2014; Braunstein and Taylor 2017; Gorski 2017; Whitehead and Perry 2020), we define "Christian nationalism" as an ideology that idealizes and advocates the fusion of American civic life with a particularly ethnicized and exclusivist strain of Christianity. Though pervasive among white evangelicals, the "Christianity" of Christian nationalism does not necessarily refer to orthodox theological beliefs as much as a conservative ethno-cultural and political orientation. Research on Christian nationalism suggests this ideology combines several different elements including (1) moral traditionalism rooted in hierarchical social arrangements (e.g., patriarchy, heterosexism), (2) authoritarian social control that justifies violence and militarism, and (3) strict ethnoracial boundaries surrounding national membership, civic participation, and social belonging (Davis 2018, 2019; Davis and Perry 2020; Delehanty et al. 2019; McDaniel et al. 2011; Sherkat and Lehman 2018; Stewart et al. 2018). This last element manifests itself in Christian nationalism being powerfully associated with indicators of xenophobia, Islamophobia, and anti-Black prejudice, particularly among white Americans (Braunstein 2017; Gorski and Perry 2022; McDaniel et al. 2011; Perry and Whitehead 2019).

It is the combination of all three elements that lead us to expect Christian nationalism would lie at the heart of contemporary ideological justification for legally restricting the vote to a 
select group of Americans deemed "worthy" to hold the reigns of governance-namely, those most likely to preserve a "conservative" status quo with white, natural-born, "Christian" citizens atop the hierarchy. The moral traditionalism rooted in social hierarchies leads Americans to view citizens in terms of being more or less "worthy" to participate in American civic life. Participation in the political process is viewed less as a right to which everyone should have equal access. Rather, because Americans are appropriately divided into contributors and freeloaders (Marti 2020), voting should therefore be restricted (or at least made more accessible) to those properly atop the hierarchy. The second element of Christian nationalism, authoritarian social control, justifies the use of institutional means to remove voting "privileges" from the "unworthy," either by tests given to weed out those who do not pass a determined threshold for civic contribution (e.g., civics tests, literacy tests, removing names from voter registrations for lack of previous participation) or moral decency (e.g., felon disenfranchisement). And the final element, ethnoracial boundaries around civic participation, provides a natural target for voter suppression by explicitly identifying those thought to be most "unworthy" to govern, or worse, trying to subvert the "integrity" of the vote through voter fraud-namely, Blacks and immigrants (McDaniel et al. 2011; Whitehead and Perry 2020). Though these three elements-hierarchical moral traditionalism, authoritarian control, and ethnoracial boundary maintenance-could theoretically be analyzed separately, we follow Whitehead and Perry (2020) who argue that Christian nationalism in the US context unites these three, infusing them with the ultimacy and polysemic utility of religious language. Christian nationalist ideology, in other words, cannot be reduced to constituent elements, but is rather weaponized against democracy as a coherent frame. Though political conservatives and GOP operatives have often advocated for fewer voters and even various kinds of voter suppression for the sake of their own political advantage, 
the influence of Christian nationalist ideology on such views is often wholly unrecognized.

Perhaps the most infamous articulation of the New Right stance on voting was that of Paul Weyrich, who famously co-founded the American Legislative Exchange Council (ALEC) which is the source of voter ID laws and other legislation aimed at restricting the vote. Yet it is perhaps less well-known that Weyrich was also the co-founder of the Moral Majority (with Jerry Falwell Sr.) and his most famous quote on voting was directed toward an audience that included Christian Right leaders such as Tim LaHaye, Pat Robertson, James Robison, W. A. Criswell, Phyllis Schlafly, and GOP Presidential hopeful Ronald Reagan:

Now many of our Christians have what I call the goo-goo syndrome-good government. They want everybody to vote. I don't want everybody to vote. Elections are not won by a majority of people, they never have been from the beginning of our country and they are not now. As a matter of fact, our leverage in the elections quite candidly goes up as the voting populace goes down.

Weyrich was consciously speaking to an audience subscribing to Christian nationalist ideology who understood the phrase "our leverage in elections" as conservative Protestants who would prefer to see fewer citizens voting in order to maximize their electoral advantage. Similarly, longtime conservative activist and author of The Power of the Christian Woman (1981) and No Higher Power: Obama's War on Religious Freedom (2012), Phyllis Schlafly explained the strategy in restricting early voting leading up to the 2012 Presidential election:

The reduction in the number of days allowed for early voting is particularly important because early voting plays a major role in Obama's ground game. The Democrats carried most states that allow many days of early voting, and Obama's national field director admitted, shortly before last year's election, that 'early voting is giving us a solid lead in the battleground states that will decide this election.'

Like Weyrich, Schlafly recognized that policies making voting easier, particularly for minorities or others who might not otherwise be able to vote on election day, works against conservative victories and thus advocated reducing early voting for no other reason than leverage. Elsewhere, 
Christian nationalist leaders simply express a desire (if not a specific policy) to limit voting access. Former Baptist Pastor, Governor of Arkansas, and GOP Presidential Candidate Mike Huckabee told an interviewer:

I know that most politicians say we want everyone to vote, I'm gonna be honest with you, I don't want everyone to vote. If they're so stupid - that's right, if they're gonna vote for me they need to vote, if they're not gonna vote for me they need to stay home. I mean, it's that simple...But in the big picture, there are people who vote and they have no idea what our Constitution says.

This last part of Huckabee's quote is instructive in that he ties citizens' worthiness to vote not only to their support for him, but to their knowledge of the Constitution.

Although these quotes do not explicitly articulate a desire to limit voter access in order ensure Christian electoral victories, it must be kept in mind we do not mean Christian nationalism as a push for strictly theocratic dominion. Rather, we propose Christian nationalism identifies real Americans as those within the conservative (Christian) cultural and political tribe (the unspoken assumption of Weyrich, Schlafly, and Huckabee). It is fundamentally about ethnocultural group boundaries and privilege, and not primarily about religion qua religion, but instead religion-as-culture and identity. This understanding of Christian nationalism is why we can classify Donald Trump - a notoriously impious person — as an exemplar of Christian nationalist assumptions if not ideology, having twice ran on a boldly Christian nationalist platform (Gorski and Perry 2022; Whitehead et al. 2018) with strong support from leaders on the Religious Right. In Spring 2020, Trump dismissed a Democratic-led push for voter reforms during the COVID-19 pandemic. Those reforms included voting by mail, same-day registration, and early voting so as to minimize infections and ensure that persons who wanted to vote safely could do so more easily. Explaining his rationale in a March 2020 phone call to Fox \& Friends, Trump stated: "The things they had in there were crazy. They had things, levels of voting that if you'd 
ever agreed to it, you'd never have a Republican elected in this country again" (Levine 2020). Following Trump's subsequent loss in November 2020, he has relentlessly pushed baseless accusations of voter fraud, many of which continue to be promulgated by his closest supporters on the Christian Right, including staunch Christian nationalists like Eric Metaxas, David Barton, David Brody, Cal Thomas, Tony Perkins, Charlie Kirk, Jenna Ellis, and Lance Wallnau (Gorski and Perry 2022). As Christian nationalism has become inextricably linked with the GOP platform over decades, culminating in Trump's 2016-2020 presidency (Baker, Perry, and Whitehead 2020; Gorski 2017; Stroop et al. 2020), we theorize that it likewise underlies contemporary views toward voting and voter access above and beyond partisan identification and ideology, traditional measures of religious conservatism, or even perceptions of racial threat.

\section{HYPOTHESES}

Given the historic efforts and inclination of the Right toward voter suppression and disenfranchisement and our theorized link between Christian nationalist ideology and contemporary ideological support for such efforts, we propose a number of hypotheses. First, because Christian nationalist ideology is fundamentally anti-egalitarian and anti-democratic, we anticipate that Christian nationalism is generally associated with a disinclination to see all Americans vote, even if they are doing so legally.

H1: Adults who more strongly affirm Christian nationalism will be less favorable toward the concept of all legally eligible Americans voting.

Related to this, because Christian nationalism would likely incline Americans toward viewing civic participation as a privilege to be earned (and importantly, one that can be taken away) rather than a right, we expect Christian nationalism is associated with a view that voting is not too difficult, but is in fact too easy, suggesting that perhaps it should be made more difficult. 
H2: Adults who more strongly affirm Christian nationalism will feel that voting is too easy rather than too difficult.

Building on this underlying premise that voting should not necessarily be exercised by all citizens, and is perhaps too easy to do already, we naturally expect Christian nationalism to be associated with skepticism that voter suppression is a hindrance these days.

H3: Adults who more strongly affirm Christian nationalism will be less likely to see voter suppression as a significant problem.

The flipside of this is that Christian nationalism would likely incline Americans toward suspicion that "unworthy" Americans (those who are perhaps ignorant, criminal, immigrants, or simply those with the wrong views) seek to steal elections through voter fraud, just as we have witnessed since Donald Trump's defeat in November 2020. And though accusations of voter fraud are highly partisan and have a long history with the Right (Atkeson et al. 2014; Wilson and Brewer 2013), we anticipate that Christian nationalist ideology predicts such attitudes above and beyond partisan identification and political ideology.

H4: Adults who affirm Christian nationalism will be more likely to express concerns about rampant voter fraud.

We also expect that the hierarchical-authoritarian and boundary-enforcing elements of Christian nationalist ideology would incline Americans toward favoring policies that formally restrict access to voting. Such policies have included arbitrary "tests" that whites could use to disenfranchise minority citizens (Anderson 2018; Berman 2015). And in recent decades, conservatives have proposed that Americans be able to pass a "civics test" in order to weed out "ignorant voters" (which historically is code language for the "unwashed" who lack the education and values of those in power; see Anderson 2018; Roth 2016). And we already documented partisan disagreements regarding the practice of felon disenfranchisement that effectively eliminates a disproportionate number of minority citizens from voting either 
temporarily or for life (Uggen and Manza 2002). We predict Christian nationalism would be associated with both strategies.

H5: Adults who affirm Christian nationalism will be more likely to favor limiting voting privileges to those who demonstrate group membership through general civic achievement or moral worthiness.

Last, previous research suggests that Christian nationalist ideology is at its most pernicious among men and white Americans (Davis and Perry 2020; Gorski and Perry 2022; Perry and Whitehead 2019). This is unsurprising because its three main elements-moral traditionalism rooted in social hierarchies, authoritarian control, and ethnoracial boundary formation-naturally favors those atop the American social hierarchy-men and whites. Thus, we test for interactions with gender and racial identity to discern whether the influence of Christian nationalism is particularly salient among men and white Americans compared to women and racial minorities, respectively. In light of previous research, we expect:

H6a: Any association between Christian nationalism and desire to restrict or suppress votes will be stronger for men than for women.

H6b: Any association between Christian nationalism and desire to restrict or suppress votes will be stronger for whites than for non-whites.

\section{METHOD}

\section{Data}

We test these hypotheses using data from Waves 1 and 5 of the Public Discourse and Ethics Survey (hereafter PDES) (Perry and Grubbs 2020). Wave 1 was collected in August 2019; Wave 2 in February of 2020; Wave 3 in May 2020; Wave 4 in August 2020; and Wave 5 in October 2020, several weeks before the November $3^{\text {rd }}$ elections. Survey waves were designed by the authors and the survey instrument was fielded by YouGov, an international research data and analytics company. YouGov recruits a panel of respondents through websites and banner ads. 
These respondents are not paid directly but are entered into lotteries for monetary prizes. In order to draw a nationally representative sample, YouGov employs a method called "matching." Drawing a random sample from the American Community Survey, YouGov then matches a respondent in the opt-in panel who is the closest to the Census respondent based on key sociodemographic factors. Because of the specific recruitment and sampling design used by YouGov, the company does not publish traditional response rates. However, YouGov develops sampling weights in order to ensure that the survey sample is in line with nationally representative norms for age, gender, race, education, and census region. Results from the PDES compare favorably with results from the 2018 General Social Survey on demographic factors such as age, gender, race, marital status, region, educational attainment, and evangelical affiliation (see Appendix Table A1). The resulting original survey sample included 2,519 Americans that were matched and weighted. Due to sample attrition between waves and a very modest amount of missing data, our final analytic samples contain between 1,217-1,219 cases in full models.

\section{Attitudes toward General Voter Access, Voter Suppression/Fraud, and Disenfranchisement}

The PDES Wave 5 contained six questions regarding Americans' attitudes toward voting and voter access. Questions were asked in such a way that researchers could assess Americans' general views about whether they think it is a good thing for as many people to vote as possible; their views on the prevalence of voter suppression and fraud; and whether they would support forms of voter disenfranchisement. Individual statements included: "Our country would be better off if every single citizen who can legally vote actually did so," "In some ways I think we make it too easy to vote," "Voter suppression in presidential elections is a real problem these days," "Voter fraud in presidential elections is getting rampant," "I would support a requirement in 
which persons must pass a basic civics test in order to vote," and "I would support a law that revoked the voting rights of certain criminal offenders for life." Response options ranged from 1 $=$ strongly disagree to $5=$ strongly agree. Because there were five values in each measure, we used ordinary least squares (OLS) regression as our model estimation strategy. ${ }^{4}$

\section{[TABLE 1 ABOUT HERE]}

\section{Christian Nationalism}

While there have been several measures of Christian nationalism (e.g., Davis 2019; Froese and Mencken 2009; Gorski and Perry 2022; McDaniel et al. 2010; Whitehead and Perry 2020), all with similar results, our measure is a scale constructed from measures repeatedly asked in surveys like the Baylor Religion Surveys and the Chapman University Survey of American Fears (Baker et al. 2020; Whitehead et al. 2018). This scale typically includes six level-ofagreement questions using the same statements: "The federal government should advocate Christian values," "The federal government should declare the United States a Christian nation," "The federal government should enforce strict separation of church and state (reverse coded)," The federal government should allow religious symbols in public spaces," "The federal government should allow prayer in public schools," and "The success of the United States is part of God's plan.” Responses range from $1=$ strongly disagree to $5=$ strongly agree. Following previous research, we combine these measures into an additive scale (set to zero) ranging from 024, with higher scores indicating greater adherence to Christian nationalism (Cronbach's alpha $=$ .90). Our Christian nationalism measures were all taken from Wave 5 of the PDES. ${ }^{5}$

\footnotetext{
${ }^{4}$ We also estimated models using ordinal logistic regression and results were virtually identical in substance and statistical significance (though all but one set of models failed the proportional odds assumption (see Appendix Table A2).

${ }^{5} \mathrm{We}$ also tested the Christian nationalism scales measured in earlier waves of the PDES and the results are substantively identical.
} 


\section{Control Variables}

Analyses also included a variety of controls theorized to be potentially connected to both Christian nationalist ideology and Americans' views about voter participation and access. All sociodemographic controls are from Wave 1 and included measures for gender $($ male $=1)$, race (dummy variables: white [reference], Black, Latino, Asian, Other race), age (in years), marital status (married $=1)$, parental status (children under $18=1)$, educational attainment $(1=$ less than high school, 6 = postgraduate degree), family income (dummy variables: zero to $\$ 29,999$ per year [= reference], $\$ 30,000-59,999$ per year, $\$ 60,000-99,999$ per year, $\$ 100,000-199,999$ per year, $\$ 200,000$ or more, did not report), and region (dummy variables: South [reference], Northeast, Midwest, West).

Political and religious characteristics are obviously critical to include when inquiring about Americans' views on voting since Christian nationalism may simply be a proxy for political and/or religious conservatism. These controls are also from Wave 1. Political controls include a series of dummy variables for party identification (Republican [reference], Democrat, Independent, Other, Don't Know), and political ideology (Very Liberal [reference], Liberal, Moderate, Conservative, Very Conservative, Not Sure). Religion controls include religious tradition and religiosity. Religious tradition is measured with six categories that were included in models as a series of dummy variables (Evangelical Protestant [reference], Liberal Protestant, Catholic, Other Christian, Other Religion, and Seculars [including atheists, agnostics, and the unaffiliated]). ${ }^{6}$ Religiosity is a summative scale from three standardized measures: religious

\footnotetext{
6 "Evangelical Protestants" are those respondents who indicated they were "Protestant" and then on a separate question indicated they were "born again or evangelical." This makes this measure similar to that used by Pew and other polling firms, with the exception that polling firms also constrain this category further by specifying "white evangelical Protestants." Liberal Protestants, in contrast, are those Protestants who indicated they were not "born again or evangelical." "Other
} 
service attendance, prayer frequency, and respondents' self-reported importance of religion in their lives (Cronbach's alpha $=.85) .^{7}$

Lastly, we included three measures to account for Americans' perceptions of racial threat or relative privileging of ethnoracial groups. In Wave 5 respondents were asked, "How much discrimination do the following groups experience these days?" and response options ranged from $1=$ none at all to $4=$ a lot. Because voter suppression and disenfranchisement has historically been in response to the political threats whites perceive from both Blacks and immigrants (Anderson 2018; Bentele and O’Brien 2013; McKee 2015), we include the measures of respondents' perceptions of discrimination against whites, African Americans/Blacks, and Immigrants. ${ }^{8}$ For descriptive statistics on all variables included in the analyses, see Table $1 .{ }^{9}$

\section{[TABLE 1 ABOUT HERE]}

\section{Plan of Analysis}

Christians" refers to Mormons and Eastern Orthodox Christians who do not have large enough numbers to be included separately but nonetheless should be included in the analysis. "Other Religions" included all non-Christian religious faiths (Jewish, Buddhist, Hindu, Muslim, etc.). ${ }^{7}$ As the alpha score indicates, the three religiosity measures are highly correlated (Pearson's r all $>$.62) and thus we include them in a scale here. However, we ran ancillary analyses with the measures separated and this did not change the substantive findings at all. Previous waves of the PDES also include measures about Bible use and attitudes. Unfortunately, these measures were asked almost exclusively of self-identified Christians or Bible-readers in the sample and thus including them here would reduce sample size tremendously.

${ }^{8}$ Though these are predictably somewhat correlated, we entered each in the multivariate models separately in order to assess the independent effect of each on the outcome and its association with Christian nationalism.

${ }^{9}$ Because research has found that exposure to right-wing media is associated with belief in rampant voter fraud (Wilson and Brewer 2013) we also sought to incorporate measures of media consumption. An earlier wave of the PDES had measures about how much trust respondents put in mainstream news sources (e.g., CNN, MSNBC, New York Times, Washington Post, NPR, etc.) or in more right-wing media (Fox News and Breitbart). We made a scale for trust in mainstream or right-wing media. We did find that both measures were associated with views regarding voter access. However, their inclusion in models did not change the dominant effect of Christian nationalism and also reduced sample size. Thus we only report those associations here rather than include them in final models. 
The analysis proceeds as follows. Tables 2 present OLS regression models testing our hypotheses. Models 1 and 2 predict Americans' views on general voter access. Models 3 and 4 predict views on voter suppression and fraud. And Models 5 and 6 predict support for restricting the vote to those who can pass a civics test or who have not committed certain crimes. All models in Table 2 include both unstandardized $(b)$ and standardized $(\beta)$ beta coefficients in order to evaluate both substantive and statistical significance. Table 3 presents unstandardized beta coefficients from OLS models with interaction terms for Christian nationalism by gender and race for all outcomes.

\section{FINDINGS}

Results from Model 1 in Table 2 do not confirm our first expectation (H1) regarding the unquestioned good of voter participation, but Model 2 does support our second hypothesis (H2) regarding ease of voter access. Specifically, Christian nationalist ideology is statistically unrelated to support for the concept of every legally eligible citizen actually voting. ${ }^{10}$ Also in Model 1 of Table 2, being older, more religious, and feeling that Blacks receive a lot of discrimination are positively associated with support for everyone voting, while being male and more politically conservative are negatively associated with this view. While this pattern was unexpected for the first outcome, in Model 2 we see Americans who affirm Christian nationalism

\footnotetext{
${ }^{10}$ Analyses of trend patterns for Christian nationalism on this outcome reveal that the association was in fact curvilinear. When we add a quadratic term for Christian nationalism to Model 1 (see online Appendix Table A3), both the original term $(b=.079, p<.001, \beta=.496)$ and quadratic term $(b=-.003, p<.001, \beta=-.483)$ are strongly significant in opposite directions indicating that as Christian nationalism increases from zero, Americans are more in favor of all eligible voters participating. But after the mid-point on the Christian nationalism scale, belief that the country would be better if all eligible Americans voted declines. This would suggest that moderate adherents to Christian nationalism are the most in favor of all eligible Americans voting, while those on the extreme left or right regarding Christian nationalism are more reluctant to support voter participation for all eligible Americans. Because we did not hypothesize these trends, but discovered them in supplementary analyses, we report them here and in the online Appendix.
} 
are indeed more likely to believe that we as a country make it "too easy to vote" $(b=.056, p<$ $.001, \beta=.281)$. Indeed, Christian nationalism is the leading predictor of believing voting is too easy, even above Democratic party (vs. Republican) identification and political ideology or beliefs about discrimination against whites, Blacks, and immigrants.

Model 3 tests our third hypothesis (H3) regarding voter suppression and Model 4 tests our fourth hypothesis (H4) regarding voter fraud, and we see that both are supported. In fact, Christian nationalism is the second leading predictor that Americans disagree that voter suppression in presidential elections is a big problem these days $(b=-.036, p<.001, \beta=-.184)$ only behind believing Black Americans experience a lot of discrimination; and it is the leading predictor that Americans agree voter fraud is getting rampant $(b=.078, p<.001, \beta=.382)$. In each of these models, again, Christian nationalism is a stronger predictor of either assessment of the legitimacy of the voting process than either political party affiliation or political ideology.

Models 5 and 6 allow us to test expectations about Americans' support for more explicit means of voter disenfranchisement. Supporting H5, in Model 5 Christian nationalism is again the leading predictor that Americans would support a measure restricting voting access to those who pass a basic civics test $(b=.036, p<.001, \beta=.184)$, followed by denying that Blacks face much discrimination these days $(b=-.208, p<.01, \beta=-.125)$, identifying as Democrat vs. Republican $(b=-.276, p<.05, \beta=-.96)$, and believing whites face a considerable amount of discrimination $(b=.132, p<.01, \beta=.90)$. Similarly in Model 6 , Christian nationalism is also the leading predictor that Americans would support a law revoking the voting rights of certain criminal offenders for life $(b=.048, p<.001, \beta=.233)$. As before, Christian nationalism is followed in magnitude by indicators of political ideology, political identity, and belief that either Blacks or whites face more discrimination these days. 


\section{[TABLE 2 ABOUT HERE]}

Finally, Table 3 presents models predicting all outcomes with interaction terms for Christian nationalism $\times$ male and Christian nationalism $\times$ each racial dummy variable. Results partially affirm our sixth hypotheses (H6a and H6b) regarding how gender and race moderate Christian nationalism's effect. Across outcomes, we can see that the term for Christian nationalism $\times$ male is statistically significant (marginal in the case of voter fraud) and in the direction that suggests Christian nationalism's influence on making Americans more inclined to restrict voter access is stronger among men more than women. Analyses of trend lines in ancillary analyses, however, suggests that these differences, though statistically significant, are not particularly notable.

A more powerful interaction exists between Christian nationalism $\times$ Black Americans $(b$ $=.061, p<.001)$ and to a lesser extent Christian nationalism $\times$ Hispanics $(b=.035, p<.01)$ regarding the belief that voter suppression in Presidential elections is a serious problem. Though the main effect for Christian nationalism remains negative, the interaction term for Christian nationalism $\times$ Blacks or Hispanics is positive indicating that compared to whites, their beliefs about voter suppression do not decline at the same rate as Christian nationalism increases.

Figure 1 illustrates the difference for Black and white Americans. As Christian nationalism increases, whites' belief that voter suppression in Presidential elections is a problem plummets. ${ }^{11}$ For Black Americans, however, there is essentially no change in their belief about voter suppression across adherence to Christian nationalism, indicating that Christian nationalism does not incline Black Americans to deny the reality of voter suppression. In fact,

\footnotetext{
11 Though the interaction effect for Christian nationalism $\times$ Hispanics was statistically significant, plotting a trendline for Hispanics indicated that their belief in voter suppression also declines with Christian nationalism and the trend does not diverge notably from that of whites.
} 
the trend line even ascends slightly. This is likely because Christian nationalism does not activate ethno-traditionalist impulses for Black Americans as it does for whites. On the contrary, as Perry and Whitehead (2019) have documented, Black Americans are more likely to view America's "Christian heritage" aspirationally. This is consistent with the rhetoric of historic Black leaders like Frederick Douglass and Martin Luther King Jr. who leveraged America's self-identity as "Christian" to call America to account for the professed democratic values it has yet to realize.

\section{[TABLE 3 AND FIGURE 1]}

\section{DISCUSSION AND CONCLUSIONS}

Because voting is democracy, and thus, free and fair elections are the bedrock foundation of the democratic process, it is imperative to understand the ideological underpinnings of antidemocratic efforts to suppress voter participation and disenfranchise citizens. Though such efforts have been prominent on the (Religious) Right for decades, studies tend to focus on extreme partisanship or racial resentment as the central drivers behind the efforts or public support for them. Almost completely absent is the recognition that religion, and specifically the political theology that sanctifies social hierarchies and privileges ethnocultural supremacy in the public sphere, has always been present among those hoping to restrict the vote.

Using a nationally representative sample of American adults, we show that a particular political theology that shrouds authoritarian ethno-nationalism with religious rhetoric - Christian nationalism - is consistently and powerfully associated with greater support for restricting the vote. Specifically, Americans who more strongly embrace Christian nationalism are more likely to believe that it is "too easy to vote," voter fraud is rampant, and voting should be denied to those who could not pass a basic civics test or who have committed certain crimes (for life). And these same Americans are much less likely to believe that voter suppression exists. 
Crucially, these relationships exist even when we account for those factors historically thought to be the central drivers of such attitudes: political party identification, political ideology, or perceptions of racial or ethnic threat. The effects also transcend general religious characteristics such as affiliation and religiosity, indicating that Christian nationalism does not capture "religion" per se, but a unique orientation to religion-as-culture and political life rooted in expectations of political power. In fact, we find in particular instances this relationship is significantly accentuated among men and white Americans, two groups who have consistently enjoyed mostly unfettered access to the levers of political power. These findings suggest that Christian nationalism — though clearly related to issues of partisanship, political ideology, and ethnocentrism - functions as a unique ideological frame that bolsters ambitions to limit political participation such that those who have historically benefitted from the status quo continue to do so. In no uncertain terms, Christian nationalism simultaneously conceals and sanctifies antidemocratic sentiment with religious and patriotic symbolism.

Prior research demonstrates how several of the elements that comprise Christian nationalism explicate its association with desires to preserve white, natural-born, and religiously and politically conservative Americans' priority access to political power. First, moral traditionalism rooted in social hierarchies serves to designate the citizens worthy of having a say in the body politic, generally those already at the top. Second, the undercurrents of authoritarian social control inherent to Christian nationalist ideology baptizes the use of institutional means to designate those who are allowed to participate. Civics tests, literacy tests, ID laws, "cleaning" voter registrations, or disenfranchising those convicted of a past crime are all acceptable means through which those in power can achieve such ends. Finally, the ethnoracial boundaries intrinsic to Christian nationalism serve to designate the targets of voter suppression-Black Americans 
and immigrants - believing that such groups would not be able to responsibly govern, or even worse, would subvert the integrity of the democratic process through voter fraud.

These findings demonstrate the importance of accounting for Christian nationalism in future studies of Americans' views toward voter suppression and disenfranchisement. Previous work (though critically valuable) has often seemed to reduce legislative and public debates over these issues to partisan affiliation and political ideology perhaps driven by undercurrents of racial threat or resentment. Though undeniably true, we have demonstrated that focusing exclusively on these factors not only fails to explain all of the relevant influences at play, it may fail to catch the most important ones. Despite accounting for these influences, Christian nationalism was still the strongest predictor in four out of six models, and the second-strongest predictor in one. Thus is essential to recognize Christian nationalist ideology as equally important to understanding Americans' views on these issues. Even more broadly, researchers must begin to see Christian nationalism as a necessary measure to include in any data collection focused on the behaviors and attitudes of the American public, whether the study is focused on the political sphere or another aspect of civil society. The burgeoning literature around Christian nationalism demonstrates that this particular ideology is fundamental to explicating how Americans perceive of and act within their social worlds, including the democratic process.

As with all studies, several limitations of the present work deserve mention. First, though specific policy examples were mentioned regarding voter restriction (passing a civics test) or disenfranchisement (denying the vote to criminal offenders for life), the PDES did not ask about one of the most controversial and persistent issues of debate: voter ID laws. Though we are confident given our study's findings Christian nationalism would be closely associated with Americans' support for more strict voter ID laws, future studies would obviously look to 
substantiate that link with explicit measures. Second, while voter suppression and disenfranchisement are two pressing concerns in our current democratic system, gerrymandering and the Electoral College are also quite effective in tilting the scales of the electoral process in favor of the Republican Party. It is important that future work examine the association between attitudes toward gerrymandering and the Electoral College in light of views of the United States as a Christian nation. Understanding the full collection of threats to a fair and free democratic process and the distribution of power via political control — at either the local, state, or federal levels - continue to be of utmost importance. Additionally, though we have accounted for what we felt were the theoretically most important confounds from previous literature, and conducted supplementary analyses to test for trust in right-wing media, to reduce the possibility of omitted variable bias, future studies would ideally look to factors like right-wing media exposure, consumption of Christian nationalist history, or some other input that could promote both Christian nationalist ideology and support for restricting voter access. Finally, while we gathered this data just before a federal election, it could be that Americans' views on these issues shift in intervening years. Such shifts may make it more or less difficult for elected officials or others to mount any sort of sustained response. However, we are unable to address that possibility here.

Nevertheless, the implications of these findings are profound. According to Whitehead and Perry (2020), over half of the United States population embraces Christian nationalism to some extent, with a fifth of American adults embracing it so strongly they fall above one standard deviation above the mean on the Christian nationalism scale. This suggests that substantial numbers of Americans are primed to support arguments aimed at limiting access to voting rights. In fact, many have and will continue to see such efforts as integral to the Christian God's desires for this county. Legitimizing anti-democratic efforts in the transcendent provide 
political cover for most any action. For if "God" desires a certain group to emerge victorious, democracy should not get in the way. It is no surprise then that political operatives on the religious and political right have for decades worked to instill the seemingly innocuous belief that America is and should be a Christian nation among a significant minority of the population to engender greater political participation (Clarkson 2018; Congressional Prayer Caucus Foundation n.d.). They sought to activate a voting bloc that was largely disengaged using appeals to "take back their country for God." Our findings demonstrate the dark side of this project. Views about America's supposedly "Christian" heritage are closely intertwined with the opinion that political participation should only be made available to some. This strikes at the heart of American democracy, to the extent it has ever truly existed at all. ${ }^{12}$ Either way, Christian nationalism is and will continue to be an existential threat to the democratic process. Those intent on broadening access to the right to vote or who desire fair and free elections must acknowledge this threat and coordinate responses in order to counter such a pervasive and powerful ideology.

\footnotetext{
${ }^{12}$ Our history clearly demonstrates that many social groups have been denied the right to vote much longer than they have had access to the voting process.
} 


\section{REFERENCES:}

Anderson, Carol. 2018. One Person, No Vote: How Voter Suppression is Destroying Democracy. New York: Bloomsbury.

Ansolabehere, Stephen, and Nathaniel Persily. 2008. "Vote Fraud in the Eye of the Beholder: The Role of Public Opinion in the Challenge to Voter Identification Requirements." Harvard Law Review 121:1738-74.

Atkeson, Lonna Rae, R. Michael Alvarez, Thad E. Hall, and J. Andrew Sinclair. 2014. "Balancing Fraud Prevention and Electoral Participation: Attitudes toward Voter Identification.” Social Science Quarterly 95(5):1381-1398.

Baker, Joseph O., Samuel L. Perry, and Andrew L. Whitehead. 2020. "Keep America Christian (and White): Christian Nationalism, Fear of Ethnoracial Outsiders, and Intention to Vote for Donald Trump in the 2020 Presidential Election." Sociology of Religion 81(3): 272293.

Banks, Antoine J., and Heather M. Hicks. 2016. “Fear and Implicit Racism: Whites' Support for Voter ID Laws.” Political Psychology 37(5):641-58.

Bean, Lydia. 2014. The Politics of Evangelical Identity: Local Churches and Partisan Divides in the United States and Canada. Princeton, NJ: Princeton University Press.

Bentele, Keith G., and Erin E. O'Brien. 2013. "Jim Crow 2.0? Why States Consider and Adopt Restrictive Voter Access Policies.” Perspectives on Politics 11(4):1088-1116.

Berman, Ari. 2015. Give us the Ballot: The Modern Struggle for Voting Rights. New York: Picador.

Bialik, Kristen. 2018. "How Americans View Some of the Voting Policies Approved at the 
Ballot Box.” Pew Research Center. https://www.pewresearch.org/facttank/2018/11/15/how-americans-view-some-of-the-voting-policies-approved-at-theballot-box/. Accessed on December 1, 2020.

Biggers, Daniel R., and Michael J. Hanmer. 2015. "Who Makes Voting Convenient? Explaining the Adoption of Early and No-Excuse Absentee Voting in the American States." State Politics \& Policy Quarterly 15(2):192-210.

Braunstein, Ruth. 2017. "Muslims as Outsiders, Enemies, and Others: The 2016 Presidential Election and the Politics of Religious Exclusion." American Journal of Cultural Sociology 5(3):355-372.

Braunstein, Ruth, and Malaena Taylor. 2017. "Is the Tea Party a "Religious" Movement? Religiosity in the Tea Party Versus the Religious Right." Sociology of Religion 78(1):3359.

Clarkson, Frederick. 2018. “"Project Blitz” Seeks to Do for Christian Nationalism what ALEC Does for Big Business.” Religion Dispatches. https://religiondispatches.org/project-blitzseeks-to-do-for-christian-nationalism-what-alec-does-for-big-business/. Accessed on December 1, 2020.

Congressional Prayer Caucus Foundation. N.D. "Vision." https://cpcfoundation.com/about/mission/. Accessed on December 1, 2020.

Conover, Pamela Johnston, and Patrick R. Miller. 2017. "How Republicans Won on Voter Identification Laws: The Roles of Strategic Reasoning and Moral Conviction.” Social Science Quarterly 99(2):490-511.

Daniels, Gilda R. 2020. Uncounted: The Crisis of Voter Suppression in America. New York: NYU Press. 
Davis, Joshua T. 2018. "Enforcing Christian Nationalism: Examining The Link Between Group Identity and Punitive Attitudes in the United States." Journal for the Scientific Study of Religion 57(2):300-17.

Davis, Joshua T. 2019. “Funding God's Policies, Defending Whiteness: Christian Nationalism and Whites' Attitudes towards Racially-Coded Government Spending." Ethnic and Racial Studies 42(12):2123-2142.

Davis, Joshua T., and Samuel L. Perry. 2020. "White Christian Nationalism and Relative Political Tolerance for Racists.” Social Problems. https://doi.org/10.1093/socpro/spaa002

Delehanty, Jack, Penny Edgell, and Evan Stewart. 2019. “Christian America? Secularized Evangelical Discourse and the Boundaries of National Belonging." Social Forces 97(3):1283-1306.

Froese, Paul, and F. Carson Mencken. 2009. “A U.S. Holy War? The Effects of Religion on Iraq War Policy Attitudes.” Social Science Quarterly 90(1):103-116.

Gorski, Philip. 2017. "Why Evangelicals Voted for Trump: A Critical Cultural Sociology." American Journal of Cultural Sociology 5: 338-54.

Gorski, Philip S., and Samuel L. Perry. 2022. The Cross and the Flag: White Christian Nationalism and the Threat to American Democracy. New York: Oxford University Press.

Grimmer, Justin, Eitan Hersh, Marc Meredith, Jonathan Mummolo, and Clayton Nall. 2018. “Obstacles to Estimating Voter ID Laws' Effect on Turnout." The Journal of Politics 80(3):1045-1015.

Hajnal, Zoltan, John Kuk, Nazita Lajevardi. 2018. "We All Agree: Strict Voter ID Laws Disproportionately Burden Minorities.” The Journal of Politics 80(3):1052-1059. 
Hajnal, Zoltan, Nazita Lajevardi, and Lindsay Nielson. 2017. "Voter Identification Laws and the Suppression of Minority Votes." The Journal of Politics 79(2):363-379.

Hartmann, Thom. 2020. The Hidden History of the War on Voting: Who Stole Your Vote and How to Get it Back. Oakland, CA: Berrett-Koehler.

Hicks, William D., Seth C. McKee, Mitchell D. Sellers, and Daniel D. Smith. 2015. “A Principle or a Strategy? Voter Identification Laws and Partisan Competition in the American States." Political Research Quarterly 68(1):18-33.

Kane, John V. 2017. "Why Can't We Agree on ID? Partisanship, Perceptions of Fraud, and Public Support for Voter Identification Laws.” Public Opinion Quarterly 81(4):943-955.

Keyssar, Alexander. 2000. The Right to Vote: The Contested History of Democracy in the United States. New York: Basic Books

Kuk, John, Zoltan Hajnal, and Nazita Lajevardi. 2020. “A Disproportionate Burden: Strict Voter Identification Laws and Minority Turnout.” Politics, Groups, and Identities. doi: $10.1080 / 21565503.2020 .1773280$

Levine, Sam. 2020. “Trump Says Republicans Would 'Never’ Be Elected Again If It Was Easier to Vote.” The Guardian. https://www.theguardian.com/us-news/2020/mar/30/trumprepublican-party-voting-reform-coronavirus. Accessed on December 1, 2020.

Manza, Jeff, Clem Brooks, and Christopher Uggen. 2004. "Public Attitudes Toward Felon Disenfranchisement in the United States.” Public Opinion Quarterly 68(2):275-286. Manza, Jeff, and Christopher Uggen. 2006. Locked Out: Felon Disenfranchisement and American Democracy. New York: Oxford University Press.

Marti, Gerardo. 2020. American Blindspot: Race, Class, Religion and the Trump Presidency. Lanham, MD: Rowman \& Littlefield. 
McDaniel, Eric L., and Christopher G. Ellison. 2008. “God's Party? Race, Religion, and Partisanship Over Time.” Political Research Quarterly 51(2):180-191.

McDaniel, Eric L., Irfan Nooruddin, Allyson Faith Shortle. 2011. "Divine Boundaries: How Religion Shapes Citizens' Attitudes Toward Immigrants." American Politics Research 39(1):205-33.

McKee, Seth C. 2015. "Politics Is Local: State Legislator Voting on Restrictive Voter Identification Legislation.” Research \& Politics 2(3):1-7.

Minnite, Lorraine C. 2010. The Myth of Voter Fraud. Ithaca, NY: Cornell University Press.

Mycoff, Jason D., Michael W. Wagner, and David C. Wilson. 2009. "The Empirical Effects of Voter-ID Laws: Present or Absent?" PS: Political Science and Politics 42(1):121-126.

O’Brien, John, and Eman Abdelhadi. 2020. "Re-examining Restructuring: Racialization, Religious Conservatism, and Political Leanings in Contemporary American Life." Social Forces 99(2):474-503.

Pinaire, Brian, and Milton Heumann. 2003. "Barred from the Vote: Public Attitudes Toward the Disenfranchisement of Felons." Fordham Urban Law Journal 30(5):1519-1550.

Perry, Samuel L., and Joshua B. Grubbs. 2020. "Formal or Functional? Traditional or Inclusive? Bible Translations as Markers of Religious Subcultures." Sociology of Religion 81(3):319-342.

Perry, Samuel L., and Andrew L. Whitehead. 2019. "Christian America in Black and White: Racial Identity, Religious-National Group Boundaries, and Explanations for Racial Inequality.” Sociology of Religion 80(3):277-298.

Perry, Samuel L., and Andrew L. Whitehead. 2021. "Racialized Religion and Judicial Injustice: 
How Whiteness and Biblicist Christianity Intersect to Promote a Preference for (Unjust) Punishment." Journal for the Scientific Study of Religion 60(1): 46-63.

Ratcliffe, Donald. 2013. "The Right to Vote and the Rise of Democracy, 1787-1828." Journal of the Early Republic 33(2):219-254.

Rocha, Rene R., and Tetsuya Matsubayashi. 2014. "The Politics of Race and Voter ID Laws in the States: The Return of Jim Crow?" Political Research Quarterly 67(3):666-679.

Roth, Zachary. 2016. The Great Suppression: Voting Rights, Corporate Cash, and the Conservative Assault on Democracy. New York: Crown.

Schlafly, Phyllis. 1981. The Power of the Christian Woman. Cincinnati, OH: Standard. Schlafly, Phyllis. 2012. No Higher Power: Obama's War on Religious Freedom. Washington, DC: Regnery.

Sherkat, Darren E., and Derek Lehman. 2018. "Bad Samaritans: Religion and Anti-Immigrant and Anti-Muslim Sentiment in the United States.” Social Science Quarterly 99(5):17911804.

Stewart III, Charles, Stephen Ansolabehere, and Nathaniel Persily. 2016. "Revisiting Public Opinion on Voter Identification and Voter Fraud in an Era of Increasing Partisan Polarization." Stanford Law Review 68: 1455-1490.

Stewart, Evan, Penny Edgell, and Jack Delehanty. 2018. “The Politics of Religious Prejudice and Tolerance for Cultural Others.” The Sociological Quarterly 59(1):17-39.

Stroope, Samuel, Paul Froese, Heather Rackin, and Jack Delehanty. 2020. "Unchurched Christian Nationalism and the 2016 U.S. Presidential Election.” Sociological Forum. Udani, Adriano, and David C. Kimball. 2018. "Making American Elections Great Again: 
Immigrant Resentment, Elite Rhetoric and Public Support for Voter Identification Restrictions.” Working Paper. doi: http://www.umsl.edu/ kimballd/meagaNov17.pdf

Uggen, Christopher, and Jeff Manza. 2002. "Democratic Reversal? The Political Consequences of Felon Disenfranchisement.” American Sociological Review 67:777-803.

Valentino, Nicholas A., and Fabian G. Neuner. 2017. "Why the Sky Didn't Fall: Mobilizing Anger in Reaction to Voter ID Laws." Political Psychology 38(2):331-50.

Waldman, Michael. 2016. The Fight to Vote. New York: Simon \& Schuster.

Wang, Tova Andrea. 2012. The Politics of Voter Suppression: Defending and Expanding Americans' Right to Vote. Ithaca, NY: Century Foundation, Cornell University Press.

Wilde, Melissa, and Lindsay Glassman. 2016. "How Complex Religion Can Improve Our Understanding of American Politics." Annual Review of Sociology 42:407-425.

Whitehead, Andrew L., and Samuel L. Perry. 2020. Taking America Back for God: Christian Nationalism in the United States. New York: Oxford University Press.

Whitehead, Andrew L., Samuel L. Perry, and Joseph O. Baker. 2018. "Make America Christian Again: Christian Nationalism and Voting for Donald Trump in the 2016 Presidential Election." Sociology of Religion 79(2):147-171.

Wilson, David C., and Paul R. Brewer. 2013. "The Foundations of Public Opinion on Voter ID Laws: Political Predispositions, Racial Resentment, and Information Effects.” Public Opinion Quarterly 77(4):962-984.

Wilson, David C., and Paul R. Brewer. 2014. "Racial Imagery and Support for Voter ID Laws." Race and Social Problems 6(4):365-71.

Wilson, David C., Paul R. Brewer, and Phoebe Theodora Rosenbluth. 2014. "Racial Imagery and Support for Voter ID Laws.” Race and Social Problems 6:365-371. 
Table 1: Descriptive Statistics

\begin{tabular}{|c|c|c|c|}
\hline Predictors & Range & Mean or $\%$ & SD \\
\hline Better If Everyone Voted & $1-5$ & 4 & 1.1 \\
\hline Too Easy to Vote & $1-5$ & 2.5 & 1.4 \\
\hline Voter Fraud Rampant & $1-5$ & 2.9 & 1.5 \\
\hline Voter Suppression A Problem & $1-5$ & 3.4 & 1.4 \\
\hline Vote if Pass Civics Test & $1-5$ & 2.7 & 1.4 \\
\hline Can't Vote for Certain Crimes & $1-5$ & 3 & 1.5 \\
\hline Christian Nationalism & $1-24$ & 10.9 & 7.1 \\
\hline Republican (reference) & $0-1$ & $28 \%$ & \\
\hline Democrat & $0-1$ & $39 \%$ & \\
\hline Independent & $0-1$ & $25 \%$ & \\
\hline Other & $0-1$ & $4 \%$ & \\
\hline Don’t Know & $0-1$ & $4 \%$ & \\
\hline Very Liberal (reference) & $0-1$ & $15 \%$ & \\
\hline Liberal & $0-1$ & $18 \%$ & \\
\hline Moderate & $0-1$ & $26 \%$ & \\
\hline Conservative & $0-1$ & $19 \%$ & \\
\hline Very Conservative & $0-1$ & $15 \%$ & \\
\hline Not Sure & $0-1$ & $6 \%$ & \\
\hline Evangelical Protestant (reference) & $0-1$ & $22 \%$ & \\
\hline Liberal Protestant & $0-1$ & $13 \%$ & \\
\hline Catholic & $0-1$ & $19 \%$ & \\
\hline Other Christian & $0-1$ & $2 \%$ & \\
\hline Other Religion & $0-1$ & $16 \%$ & \\
\hline Seculars ${ }^{\mathrm{f}}$ & $0-1$ & $31 \%$ & \\
\hline Religiosity Index & $-4.02-3.93$ & -.19 & 2.7 \\
\hline Whites Discrimination & $1-4$ & 2.2 & 1 \\
\hline Blacks Discrimination & $1-4$ & 3.2 & .9 \\
\hline Immigrants Discrimination & $1-4$ & 3.2 & .8 \\
\hline Age & $18-90$ & 52.6 & 16.3 \\
\hline Male & $0-1$ & $46 \%$ & \\
\hline White (reference) & $0-1$ & $66 \%$ & \\
\hline Black & $0-1$ & $11 \%$ & \\
\hline Hispanic & $0-1$ & $14 \%$ & \\
\hline Asian & $0-1$ & $3 \%$ & \\
\hline Other Race & $0-1$ & $5 \%$ & \\
\hline Married & $0-1$ & $51 \%$ & \\
\hline Kids Under 18 & $0-1$ & $23 \%$ & \\
\hline South (reference) & $0-1$ & $37 \%$ & \\
\hline Northeast & $0-1$ & $18 \%$ & \\
\hline Midwest & $0-1$ & $21 \%$ & \\
\hline West & $0-1$ & $24 \%$ & \\
\hline Education & $1-6$ & 3.3 & 1.5 \\
\hline Income under $\$ 30,000$ (reference) & $0-1$ & $24 \%$ & \\
\hline Between $\$ 30,000-\$ 59,999$ & $0-1$ & $31 \%$ & \\
\hline Between $\$ 60,000-\$ 99,999$ & $0-1$ & $29 \%$ & \\
\hline Between $\$ 100,000-\$ 199,999$ & $0-1$ & $13 \%$ & \\
\hline$\$ 200,000$ or More & $0-1$ & $2 \%$ & \\
\hline Didn't Report Income & $0-1$ & $10 \%$ & \\
\hline
\end{tabular}

Source: PDES Waves 1 and 5. 
Table 2: Ordinary least squares regression models predicting Americans' attitudes regarding voting access in the United States.

\begin{tabular}{|c|c|c|c|c|c|c|c|c|c|c|c|c|}
\hline \multirow[b]{3}{*}{ Predictors } & \multicolumn{4}{|c|}{ General Voter Access } & \multicolumn{4}{|c|}{ Voter Suppression/Fraud } & \multicolumn{4}{|c|}{ Disenfranchisement } \\
\hline & \multicolumn{2}{|c|}{$\begin{array}{c}\text { Model 1: } \\
\text { Better if } \\
\text { Everyone Voted }\end{array}$} & \multicolumn{2}{|c|}{$\begin{array}{c}\text { Model 2: } \\
\text { Too Easy } \\
\text { to Vote }\end{array}$} & \multicolumn{2}{|c|}{$\begin{array}{c}\text { Model 3: } \\
\text { Voter Suppression } \\
\text { A Problem } \\
\end{array}$} & \multicolumn{2}{|c|}{$\begin{array}{c}\text { Model 4: } \\
\text { Voter Fraud } \\
\text { Getting Rampant }\end{array}$} & \multicolumn{2}{|c|}{$\begin{array}{c}\text { Model 5: } \\
\text { Vote if Pass } \\
\text { Basic Civics Test }\end{array}$} & \multicolumn{2}{|c|}{$\begin{array}{c}\text { Model 6: } \\
\text { Certain Offenders } \\
\text { Lose Vote for Life }\end{array}$} \\
\hline & $\mathrm{b}$ & $\beta$ & $\mathrm{b}$ & $\beta$ & $\mathrm{b}$ & $\beta$ & $\mathrm{b}$ & $\beta$ & $\mathrm{b}$ & $\beta$ & $\mathrm{b}$ & $\beta$ \\
\hline Christian Nationalism & -.002 & -.015 & $.056 * * *$ & .281 & $-.036 * * *$ & -.184 & $.078 * * *$ & .382 & $.036 * * *$ & .183 & $.048 * * *$ & .233 \\
\hline Democrat $^{\mathrm{d}}$ & .047 & .020 & $-.472 * * *$ & -.163 & $.364 * * *$ & .126 & $-.306 * *$ & -.103 & $-.276^{*}$ & -.096 & $-.476 * * *$ & -.158 \\
\hline Independent $^{\mathrm{d}}$ & $-.189 *$ & -.073 & $-.212 *$ & -.066 & -.012 & -.004 & -.144 & -.043 & .010 & .003 & $-.262^{*}$ & -.078 \\
\hline Other ${ }^{\mathrm{d}}$ & -.126 & -.022 & -.098 & -.014 & -.005 & -.001 & -.273 & -.037 & .060 & .008 & $-.485^{*}$ & -.065 \\
\hline Don’t Know ${ }^{d}$ & $-.612 * * *$ & -.104 & -.235 & -.032 & .019 & .003 & -.329 & -.043 & .120 & .016 & .220 & .029 \\
\hline Liberal $^{\mathrm{e}}$ & $-.257 *$ & -.086 & .169 & .046 & $-.293 * *$ & -.079 & .082 & .022 & .075 & .020 & $.309^{*}$ & .080 \\
\hline Moderate $^{\mathrm{e}}$ & $-.394 * * *$ & -.154 & $.369^{* *}$ & .116 & $-.389 * * *$ & -.122 & $.326^{* *}$ & .099 & .192 & .060 & $.600 * * *$ & .181 \\
\hline Conservative $^{\mathrm{e}}$ & $-.513 * * *$ & -.178 & $.515 * * *$ & .144 & $-.615 * * *$ & -.172 & $.711 * * *$ & .193 & .314 & .088 & $.620 * * *$ & .167 \\
\hline Very Conservative $^{\mathrm{e}}$ & $-.465 * *$ & -.148 & $.487 * *$ & .124 & $-.426 * *$ & -.109 & $.785^{* * *}$ & .195 & .320 & .082 & $.782 * * *$ & .192 \\
\hline Note Sure ${ }^{\mathrm{e}}$ & -.315 & -.069 & $.600 * * *$ & .105 & -.296 & -.052 & $.692 * * *$ & .118 & .028 & .005 & .238 & .040 \\
\hline Liberal Protestant ${ }^{\mathrm{f}}$ & -.212 & -.063 & .111 & .027 & .115 & .028 & .213 & .050 & .154 & .037 & .145 & .033 \\
\hline Catholic ${ }^{\mathrm{f}}$ & -.018 & -.006 & $.434 * * *$ & .120 & .010 & .003 & $.272 * *$ & .073 & $.318 * *$ & .089 & .211 & .056 \\
\hline Other Christian ${ }^{\mathrm{f}}$ & .066 & .009 & .214 & .023 & .151 & .016 & -.067 & -.007 & .011 & .001 & -.245 & -.026 \\
\hline Other Religion $^{\mathrm{f}}$ & .107 & .030 & .184 & .042 & -.019 & -.004 & $.341 * *$ & .075 & .076 & .017 & .154 & .034 \\
\hline Seculars ${ }^{\mathrm{f}}$ & .044 & .018 & .192 & .063 & .073 & .024 & $.246^{*}$ & .079 & .067 & .022 & .070 & .022 \\
\hline Religiosity Index & $.046 *$ & .109 & -.029 & -.055 & .018 & .035 & -.015 & -.027 & -.027 & -.052 & -.037 & -.067 \\
\hline Whites Discrim. & -.066 & -.056 & $.120 * *$ & .082 & $-.143 * * *$ & -.097 & $.150 * * *$ & .099 & $.132 * *$ & .090 & $.199 * * *$ & .130 \\
\hline Blacks Discrim. & $.110^{*}$ & .082 & $-.264 * * *$ & -.159 & $.338 * * *$ & .203 & -.065 & -.038 & $-.208^{* *}$ & -.125 & $-.210 * * *$ & -.122 \\
\hline Immigrants Discrim. & $.235^{* * *}$ & .174 & $-.122 *$ & -.072 & $.199 * * *$ & .118 & -.060 & -.035 & -.057 & -.034 & -.028 & -.016 \\
\hline Age & $.012 * * *$ & .165 & -.003 & -.031 & -.002 & -.021 & -.002 & -.021 & -.004 & -.048 & $.005^{*}$ & .053 \\
\hline Male & $-.176 * *$ & -.078 & .125 & .044 & $-.148^{*}$ & -.052 & $-.261 * * *$ & -.090 & $.183^{*}$ & .065 & -.094 & -.032 \\
\hline Black $^{\mathrm{a}}$ & .136 & .038 & .081 & .018 & $.264 *$ & .060 & $.319 * *$ & .070 & -.196 & -.044 & $-.267 *$ & -.058 \\
\hline Hispanic $^{a}$ & .101 & .031 & $.347 * * *$ & .086 & .003 & .001 & $.236^{*}$ & .057 & -.078 & -.019 & .052 & .012 \\
\hline Asian ${ }^{\mathrm{a}}$ & .115 & .017 & $.476^{*}$ & .056 & .075 & .009 & $.420 *$ & .048 & $.596 * *$ & .071 & $.578 * *$ & .066 \\
\hline Other Race ${ }^{a}$ & .154 & .030 & $.497 * * *$ & .078 & .035 & .006 & $.599 * * *$ & .091 & .299 & .047 & .167 & .025 \\
\hline Married & .103 & .046 & -.012 & -.004 & -.036 & -.013 & -.086 & -.030 & -.083 & -.030 & .031 & .011 \\
\hline Kids Under 18 & -.088 & -.033 & -.016 & -.005 & -.100 & -.030 & .051 & .015 & .037 & .011 & -.143 & -.041 \\
\hline Northeast $^{\mathrm{b}}$ & -.172 & -.058 & .121 & .033 & .017 & .005 & $.194 *$ & .051 & -.141 & -.038 & .142 & .037 \\
\hline Midwest $^{\mathrm{b}}$ & -.127 & -.046 & .023 & .007 & .002 & .001 & -.052 & -.015 & -.062 & -.018 & .010 & .003 \\
\hline West $^{\mathrm{b}}$ & -.155 & -.059 & -.019 & -.006 & .100 & .031 & -.151 & -.045 & .141 & .043 & .030 & .009 \\
\hline
\end{tabular}




\begin{tabular}{|c|c|c|c|c|c|c|c|c|c|c|c|c|}
\hline Education & .000 & .000 & -.035 & -.038 & -.046 & -.050 & $-.080 * * *$ & -.084 & .011 & .012 & -.004 & -.004 \\
\hline$\$ 30,000-\$ 59,999^{c}$ & -.021 & -.008 & -.015 & -.005 & .045 & .015 & -.165 & -.053 & -.020 & -.007 & -.081 & -.026 \\
\hline$\$ 60,000-\$ 99,999^{c}$ & .145 & .051 & -.020 & -.006 & .047 & .013 & -.108 & -.030 & .025 & .007 & -.033 & -.009 \\
\hline$\$ 100,000-\$ 199,999^{c}$ & $-.271 *$ & -.080 & .035 & .008 & -.046 & -.011 & -.079 & -.018 & $.359^{*}$ & .085 & -.141 & -.032 \\
\hline$\$ 200,000$ or More ${ }^{c}$ & .040 & .005 & .134 & .012 & $-.667 * *$ & -.062 & .094 & .008 & .027 & .003 & -.400 & -.036 \\
\hline Didn't Report Income ${ }^{c}$ & -.087 & -.023 & $241^{*}$ & .052 & -.007 & -.001 & .000 & .000 & .138 & .030 & .034 & .007 \\
\hline Intercept & \multicolumn{2}{|c|}{$3.018 * * *$} & \multicolumn{2}{|c|}{$2.631 * * *$} & \multicolumn{2}{|c|}{$2.875^{* * *}$} & \multicolumn{2}{|c|}{$2.875^{* * *}$} & \multicolumn{2}{|c|}{$2.797 * * *$} & \multicolumn{2}{|c|}{$2.364 * * *$} \\
\hline Adjusted $\mathrm{R}^{2}$ & \multicolumn{2}{|c|}{.168} & \multicolumn{2}{|c|}{.403} & \multicolumn{2}{|c|}{.403} & \multicolumn{2}{|c|}{.403} & \multicolumn{2}{|c|}{.205} & \multicolumn{2}{|c|}{.361} \\
\hline $\mathrm{N}$ & \multicolumn{2}{|c|}{1,219} & \multicolumn{2}{|c|}{1,219} & \multicolumn{2}{|c|}{1,218} & \multicolumn{2}{|c|}{1,218} & \multicolumn{2}{|c|}{1,217} & \multicolumn{2}{|c|}{1,219} \\
\hline
\end{tabular}

Source: PDES Waves 1 and 5.

Note: ${ }^{a}$ reference is white; ${ }^{\mathrm{b}}$ reference is South; ${ }^{\mathrm{c}}$ reference is Income under $\$ 30,000$; ${ }^{\mathrm{d}}$ reference is Republican; ${ }^{\mathrm{e}}$ reference is "Very Liberal;" " reference is

Evangelical Protestant.

$* \mathrm{p} \leq .05 ; * * \mathrm{p} \leq .01 ; * * * \mathrm{p} \leq .001$ (two-tailed tests). 
Table 3: Ordinary least squares regression models predicting Americans' attitudes regarding voter access and participation with interactions by gender and race.

\begin{tabular}{|c|c|c|c|c|c|c|}
\hline Predictors & $\begin{array}{c}\text { Better if } \\
\text { Everyone Voted }\end{array}$ & $\begin{array}{c}\text { Too Easy to } \\
\text { Vote }\end{array}$ & $\begin{array}{c}\text { Voter } \\
\text { Suppression A } \\
\text { Real Problem } \\
\end{array}$ & $\begin{array}{c}\text { Voter Fraud } \\
\text { Getting } \\
\text { Rampant } \\
\end{array}$ & $\begin{array}{c}\text { Vote if Pass } \\
\text { Basic Civics } \\
\text { Test }\end{array}$ & $\begin{array}{c}\text { Certain } \\
\text { Offenders } \\
\text { Lose Vote for } \\
\text { Life }\end{array}$ \\
\hline Christian Nationalism & .014 & $.049 * * *$ & $-.036 * * *$ & $.074 * * *$ & $.025 *$ & $.039 * * *$ \\
\hline Male & .177 & -.102 & .166 & $-.430 * * *$ & -.075 & $-.404 * * *$ \\
\hline Black $^{\mathrm{a}}$ & .146 & .298 & -.404 & $.537 * *$ & -.162 & -.075 \\
\hline Hispanic $^{\mathrm{a}}$ & .055 & $.638 * * *$ & $-.386^{*}$ & .176 & -.273 & .043 \\
\hline Asian $^{a}$ & .346 & .132 & .019 & .506 & .291 & $.965 *$ \\
\hline Other Race ${ }^{\mathrm{a}}$ & .387 & -.049 & .226 & $.661 *$ & $.654 *$ & .180 \\
\hline $\mathrm{CN} \times$ Male & $-.033 * * *$ & $.021 *$ & $-.028 * *$ & $.016+$ & $.025 *$ & $.029 * *$ \\
\hline $\mathrm{CN} \times$ Black & -.002 & -.020 & $.061 * * *$ & -.020 & -.003 & -.017 \\
\hline $\mathrm{CN} \times$ Hispanic & .003 & -.025 & $.035 * *$ & .006 & .018 & .002 \\
\hline $\mathrm{CN} \times$ Asian & -.028 & .039 & .005 & -.009 & .035 & -.041 \\
\hline $\mathrm{CN} \times$ Other Race & -.020 & $.046 *$ & -.015 & -.006 & -.030 & -.002 \\
\hline Controls & Yes & Yes & Yes & Yes & Yes & Yes \\
\hline Adjusted $\mathrm{R}^{2}$ & .176 & .408 & .415 & .469 & .208 & .365 \\
\hline $\mathrm{N}$ & 1,219 & 1,219 & 1,218 & 1,219 & 1,217 & 1,219 \\
\hline
\end{tabular}

Source: PDES Waves 1 and 5.

Note: Unstandardized regression coefficients. Controls from Table 2 included in all models. ${ }^{\text {a }}$ reference is white. $+\mathrm{p}=.071 ; * \mathrm{p} \leq .05 ; * * \mathrm{p} \leq .01 ; * * \mathrm{p} \leq .001$ (two-tailed tests). 
Figure 1: Predicted values of believing that voter suppression in Presidential elections is a real problem across values of Christian Nationalism by race.

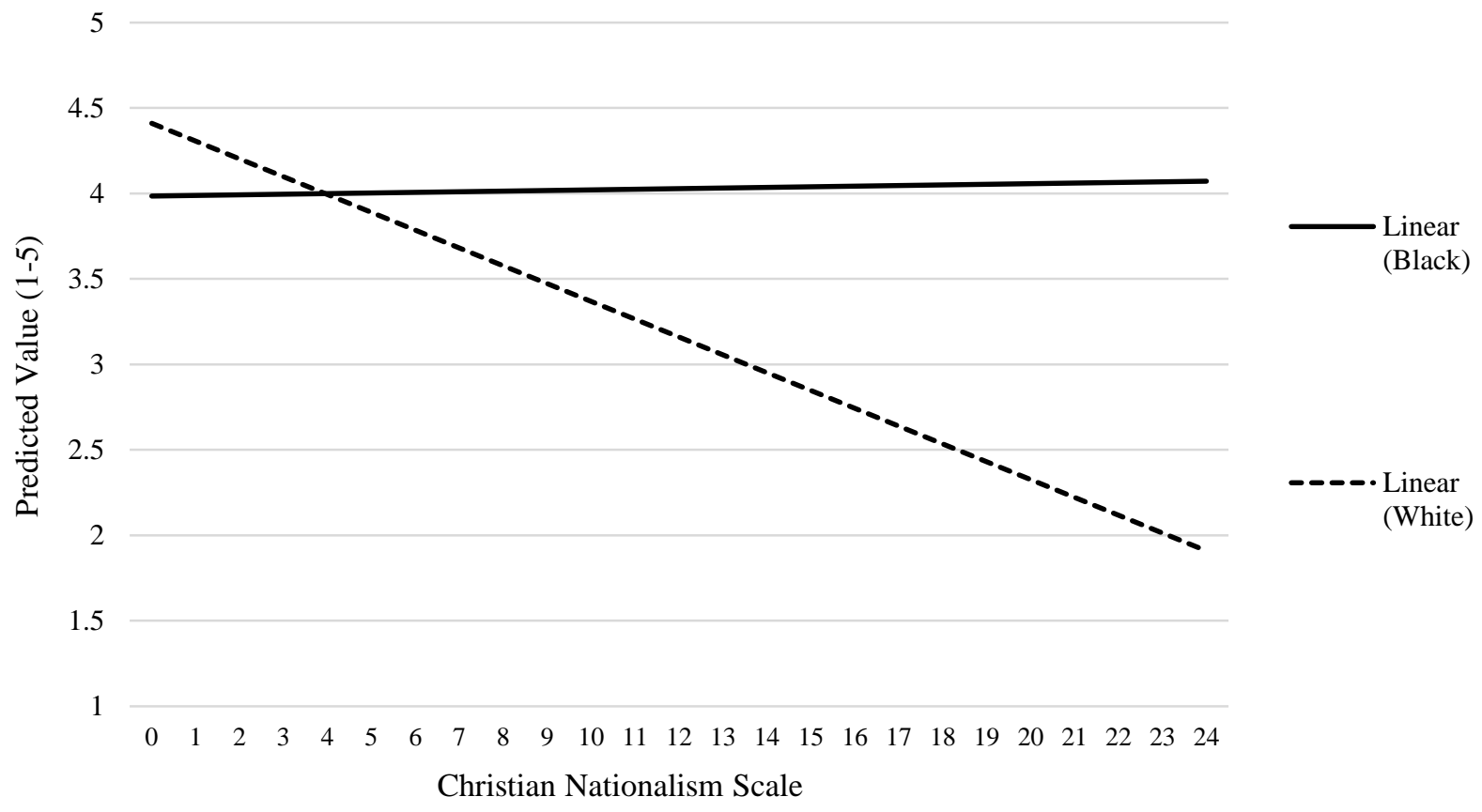




\section{ONLINE APPENDIX MATERIAL}

Table A1: Comparison of PDES W1 and 2018 GSS on Key Demographic Variables

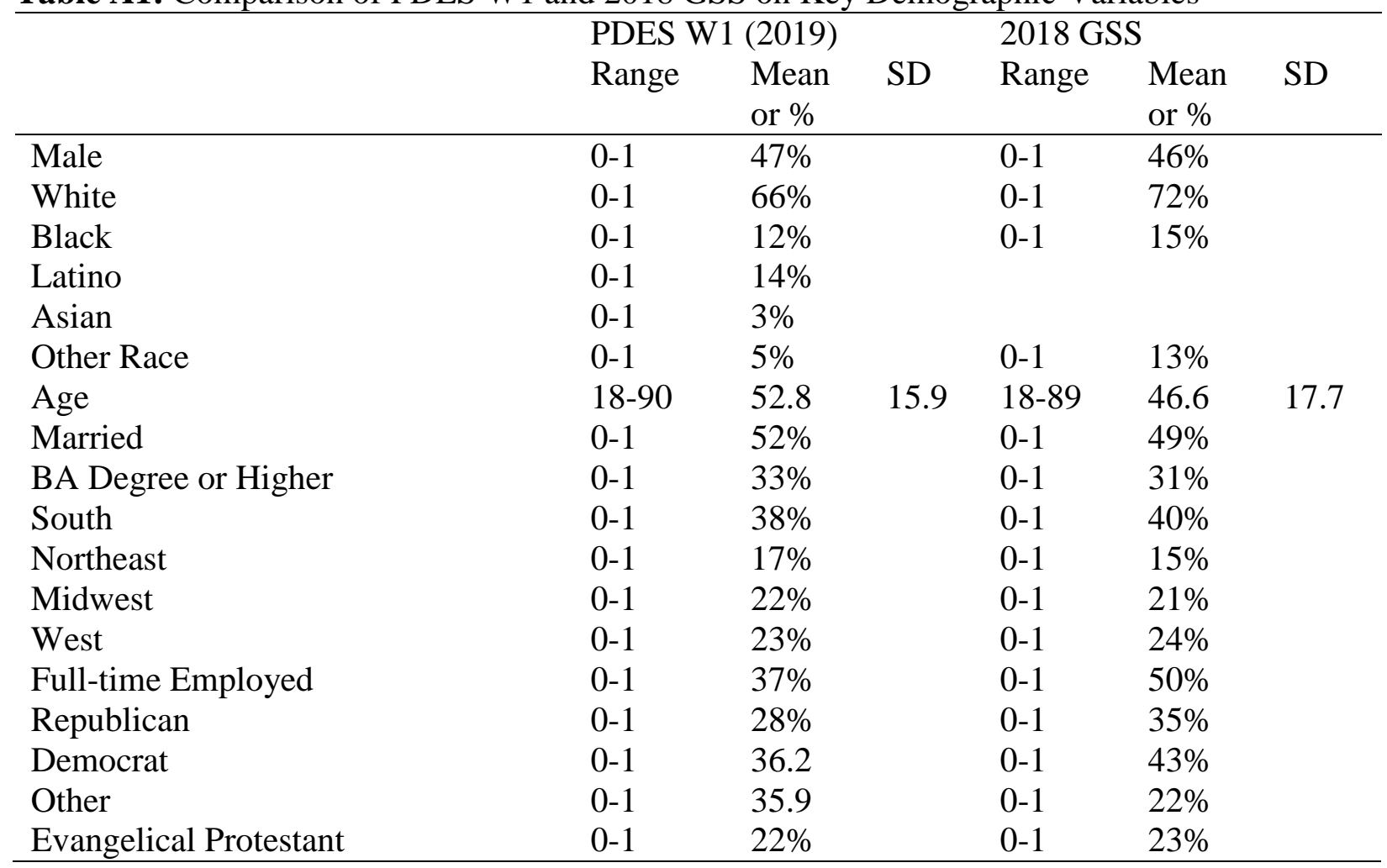


Table A2: Ordinal logistic regression models predicting Americans' attitudes regarding voter access, prevalence of voter suppression, and prevalence of voter fraud.

\begin{tabular}{|c|c|c|c|c|c|c|c|c|c|c|c|c|}
\hline \multirow[b]{2}{*}{ Predictors } & \multicolumn{2}{|c|}{$\begin{array}{c}\text { Better if Everyone } \\
\text { Voted }\end{array}$} & \multicolumn{2}{|c|}{$\begin{array}{l}\text { Too Easy } \\
\text { to Vote }\end{array}$} & \multicolumn{2}{|c|}{$\begin{array}{l}\text { Voter Suppression A } \\
\text { Real Problem }\end{array}$} & \multicolumn{2}{|c|}{$\begin{array}{c}\text { Voter Fraud Getting } \\
\text { Rampant }\end{array}$} & \multicolumn{2}{|c|}{$\begin{array}{c}\text { Vote if Pass Basic } \\
\text { Civics Test }\end{array}$} & \multicolumn{2}{|c|}{$\begin{array}{l}\text { Offenders Lose Vote } \\
\text { for Life }\end{array}$} \\
\hline & M1 & $\mathrm{M} 2$ & M3 & M4 & M5 & M6 & M7 & M8 & M9 & M10 & M11 & M12 \\
\hline Christian National. & -.001 & $.035^{*}$ & $103 * * *$ & $.095 * * *$ & $-.072 * * *$ & $-.065 * * *$ & $.131 * * *$ & $.124 * * *$ & $.055 * * *$ & $.036^{*}$ & $.080 * * *$ & $.064 * * *$ \\
\hline Male & $.022 *$ & $.528 *$ & -.005 & -.325 & .000 & .426 & -.002 & $-.940 * * *$ & -.006 & -.148 & .007 & $-.761 * * *$ \\
\hline Black $^{\mathrm{a}}$ & -.253 & .606 & .202 & .696 & $-.238 *$ & -.571 & $-.537 * * *$ & $.886^{*}$ & $.252 *$ & -.249 & -.173 & -.046 \\
\hline Hispanic $^{a}$ & .374 & .145 & $.246 * * *$ & $1.594 * * *$ & .493 & -.647 & $.594 * *$ & .523 & -.262 & -.426 & -.360 & .027 \\
\hline $\operatorname{Asian}^{\mathrm{a}}$ & .198 & .502 & $.695 * *$ & .395 & .015 & -.167 & $.476^{*}$ & 1.118 & $-.080 * *$ & .353 & $.046 * *$ & $1.626 * *$ \\
\hline Other Race ${ }^{a}$ & .089 & .704 & $.891 * *$ & .070 & .155 & .338 & $.756^{* * *}$ & $1.353^{* *}$ & .954 & $.927 *$ & .964 & .468 \\
\hline $\mathrm{CN} \times$ Male & & $-.071 * * *$ & & $.043^{*}$ & & $-.057 * * *$ & & .035 & & $.037 *$ & & $.054 * * *$ \\
\hline $\mathrm{CN} \times$ Black & & -.020 & & -.037 & & $.091 * *$ & & -.025 & & -.001 & & -.026 \\
\hline $\mathrm{CN} \times$ Hispanic & & .002 & & $-.075 * *$ & & $.054 *$ & & -.003 & & .030 & & .003 \\
\hline $\mathrm{CN} \times$ Asian & & -.049 & & .055 & & .031 & & -.036 & & .068 & & -.069 \\
\hline $\mathrm{CN} \times$ Other Race & & -.037 & & .054 & & -.025 & & -.035 & & -.045 & & -.014 \\
\hline Controls & Yes & Yes & Yes & Yes & Yes & Yes & Yes & Yes & Yes & Yes & Yes & Yes \\
\hline Threshold 1 & $-1.612 * *$ & -1.053 & -.676 & -.762 & $-1.427 * *$ & $-1.397 *$ & -.191 & -.298 & $-1.212^{*}$ & $-1.548 * *$ & -.629 & -.856 \\
\hline Threshold 2 & -.683 & -.120 & .251 & .172 & -.560 & -.515 & .628 & .532 & -.383 & -.715 & .238 & .023 \\
\hline Threshold 3 & .805 & $1.384 *$ & $1.655^{* *}$ & $1.587 * *$ & .930 & 1.000 & $2.048 * * *$ & $1.953 * * *$ & .708 & .385 & $1.545 * *$ & $1.340 *$ \\
\hline Threshold 4 & $2.031 * * *$ & $2.630 * * *$ & $2.897 * * *$ & $2.841 * * *$ & $2.271 * * *$ & $2.355 * * *$ & $3.737 * * *$ & $3.631 * * *$ & $2.094 * * *$ & $1.782 * * *$ & $2.755 * * *$ & $2.552 * * *$ \\
\hline Test of Parallel Lines & No & No & Yes & Yes & No & No & No & No & No & No & No & No \\
\hline Pseudo $\mathrm{R}^{2}$ & .205 & .219 & .450 & .459 & .454 & .465 & .485 & .488 & .244 & .252 & .390 & .398 \\
\hline $\mathrm{N}$ & \multicolumn{2}{|c|}{1,219} & \multicolumn{2}{|c|}{1,219} & \multicolumn{2}{|c|}{1,218} & \multicolumn{2}{|c|}{1,219} & \multicolumn{2}{|c|}{1,217} & \multicolumn{2}{|c|}{1,219} \\
\hline
\end{tabular}

Source: PDES Waves 1 and 5 .

Note: a reference is white; ${ }^{\mathrm{b}}$ reference is South; ${ }^{\mathrm{c}}$ reference is Income under $\$ 30,000 ;{ }^{\mathrm{d}}$ reference is Republican; ${ }^{\mathrm{e}}$ reference is "Very Liberal;" ${ }^{\mathrm{f}}$ reference is Evangelical Protestant.

$* \mathrm{p} \leq .05 ; * * \mathrm{p} \leq .01 ; * * \mathrm{p} \leq .001$ (two-tailed tests) 
Table A3: Ordinary least squares regression model predicting Americans views on voter participation with a quadratic term for Christian nationalism.

\begin{tabular}{|c|c|c|}
\hline & \multicolumn{2}{|c|}{ Better if Everyone Voted } \\
\hline Predictors & $\mathrm{b}$ & $\beta$ \\
\hline Christian Nationalism & $.079 * * *$ & .496 \\
\hline Christian Nationalism $^{2}$ & $-.003 * * *$ & -.483 \\
\hline Democrat $^{\mathrm{d}}$ & -.050 & -.022 \\
\hline Independent $^{\mathrm{d}}$ & $.189 *$ & .073 \\
\hline Other ${ }^{d}$ & .140 & .024 \\
\hline Don't Know ${ }^{\mathrm{d}}$ & $.570 * *$ & .097 \\
\hline Liberal $^{\mathrm{e}}$ & .207 & .069 \\
\hline Moderate $^{\mathrm{e}}$ & $.282 *$ & .110 \\
\hline Conservative $^{e}$ & $.415 * *$ & .144 \\
\hline Very Conservative ${ }^{\mathrm{e}}$ & $.437 * *$ & .139 \\
\hline Note Sure & .203 & .044 \\
\hline Liberal Protestant ${ }^{\mathrm{f}}$ & .122 & .036 \\
\hline Catholic $^{\mathrm{f}}$ & -.080 & -.028 \\
\hline Other Christian ${ }^{\mathrm{f}}$ & -.112 & -.015 \\
\hline Other Religion $^{\mathrm{f}}$ & -.168 & -.048 \\
\hline Seculars ${ }^{\mathrm{f}}$ & -.076 & -.031 \\
\hline Religiosity Index & $-.051 * *$ & -.120 \\
\hline Whites Discrimination & .063 & .053 \\
\hline Blacks Discrimination & -.101 & -.076 \\
\hline Immigrants Discrimination & $-.226 * * *$ & -.167 \\
\hline Age & $-.011 * * *$ & -.157 \\
\hline Male & $.174 * *$ & .077 \\
\hline Black $^{\mathrm{a}}$ & -.180 & -.050 \\
\hline Hispanic $^{a}$ & -.117 & -.036 \\
\hline Asian $^{\mathrm{a}}$ & -.135 & -.020 \\
\hline Other Race ${ }^{a}$ & -.164 & -.032 \\
\hline Married & -.100 & -.044 \\
\hline Kids Under 18 & .061 & .023 \\
\hline Northeast $^{\mathrm{b}}$ & .152 & .051 \\
\hline Midwest $^{\mathrm{b}}$ & .130 & .047 \\
\hline West $^{\mathrm{b}}$ & .151 & .057 \\
\hline Education & .002 & .002 \\
\hline Income: $\$ 30,000-\$ 59,999^{c}$ & .038 & .015 \\
\hline Income: $\$ 60,000-\$ 99,999^{c}$ & -.119 & -.042 \\
\hline Income: $\$ 100,000-\$ 199,999^{c}$ & $.278 *$ & .082 \\
\hline Income: $\$ 200,000$ or More ${ }^{\mathrm{c}}$ & -.062 & -.007 \\
\hline Didn’t Report Income ${ }^{c}$ & .105 & .028 \\
\hline Intercept & 2.76 & \\
\hline Adjusted $\mathrm{R}^{2}$ & & \\
\hline $\mathrm{N}$ & & \\
\hline
\end{tabular}

Source: PDES Waves 1 and 5.

Note: ${ }^{a}$ reference is white; ${ }^{b}$ reference is South; ${ }^{c}$ reference is Income under $\$ 30,000 ;{ }^{d}$ reference is Republican; ${ }^{\mathrm{e}}$ reference is "Very Liberal;" " reference is Evangelical Protestant.

$* \mathrm{p} \leq .05 ; * * \mathrm{p} \leq .01 ; * * * \mathrm{p} \leq .001$ (two-tailed tests). 